\title{
Pemikiran Ibn Khaldun Tentang Rasionalisme Islam: Suatu Penelitian Ringkas
}

\author{
Ahmad Nabil Amir \\ International Institute of Islamic Thought and Civilization (ISTAC-IIUM) \\ nabiller2002@gmail.com
}

\begin{abstract}
This paper briefly discusses Ibn Khaldun's philosophical and rational construction of Islam and its metaphysical discursus as set forth in his classical works such as kitab alTbar, Al-Ta'rif, Tabrir al-Abkam, and al-Muqaddimah. This works expressed his highly rational outlook that developed critical and rational understanding of religious and moral premises. It also summarized its dynamic ground that contribute to expound instructive discussion of related ideas and themes. The study is based on library research using content analysis and analyzed through analytical and descriptive approaches. The finding concludes that Ibn Khaldun has bring forth rational interpretation of history based on unique philosophical and socio-cultural analysis he introduced in his al-Muqaddimah. This characteristic approach of rational ideal has significantly impacted Islam's modern history and tradition. His rational and argumentative principle has largely influence the works of contemporary Muslim thinkers such as Malik Bennabi, Rashid Ghannoushi and Mubammad Asad.
\end{abstract}

Keywords: Islamic rationalism; school of thought; Ibn Khaldun; Kitab al-Muqaddimab;

Abstrak. artikel ini membahas falsafah pemikiran Ibn Khaldun tentang faham rasionalisme Islam seperti yang dibahaskan dalam karya-karyanya yang monumental seperti Kitab al-Tbar, Al-Ta'rif, Tabrir al-Abkam, dan alMuqaddimah. Kitab-kitab ini mengungkapkan falsafah pemikirannya yang rasional yang mempertahankan idealisme dan kefahaman agama yang kritis. Ia turut merumuskan landasan fikrahnya yang dinamis dan sumbangannya dalam menggariskan metode perbincangan teks yang instruktif. Tinjauan ini berasaskan metode penelitian perpustakaan dari jenis analisis kandungan secara deskriptif dan analitik. Ibn Khaldun telah menggariskan manhaj pemikiran yang rasional, dan komprehensif dalam perbincangan tentang sains, sejarah, budaya, peradaban, dan sosial seperti dalam al-Muqaddimah. Hasil penelitian membuktikan Ibn Khaldun telah mempelopori dasar rasionalisme yang signifikan dalam tradisi Islam. Ini dibahaskan dalam karya-karyanya yang menjadi titik perbahasan sejarah yang penting. Dari perbincangan ringkas tentang asas rasionalisme ini, tulisan memperlihatkan sumbangan pemikiran Ibn Khaldun dalam menzahirkan faham rasionalisme Islam dan pengaruhnya 
kepada pemikir Islam modern seperti Malik Bennabi, Rashid Ghannousyi dan Muhammad Asad.

Kata kunci: Rasionalisme Islam; mazhab pemikiran; Ibn Khaldun; kitab alMuqaddimah;

\section{PENDAHULUAN}

Rasionalisme Islam merupakan istilah yang dipakai untuk merujuk kepada peranan akal dalam merungkai persoalan-persoalan teologi dalam Islam (Mohd Shuhaimi Ishak, 2007: 1) Ia membayangkan posisi akal sebagai justifikasi yang fundamental terhadap pengetahuan atau keyakinan. Asas rasionalisme adalah paham bahwa Tuhan dan alam dapat dipahami melalui daya intelek yang diciptakan Tuhan dalam diri manusia. Tentang Tuhan, persepsi ini bermaksud bahawa kewujudan Tuhan, keesaanNya dan sifatsifatNya dapat diketahui melalui akal. Tentang alam, ia bermaksud bahawa kejadian alam dan strukturnya, manusia dan perbuatannya dapat dipahami secara logis. (Benyamin Abrahamov, 1998: x).

Pertimbangan rasionalisme meletakkan akal sebagai alat yang utama atau salah satu alat yang utama untuk sampai kepada kebenaran agama, dan memilih akal ketimbang wahyu dan tradisi (hadith) untuk menangani persoalan kalam terutamanya ketika bangkitnya konflik antaranya. (Hourani, 1971: 10). Perspektif dan paham rasionalisme ini berakar dari pengaruh falsafah Yunani yang masuk dan berkembang di wilayah Islam pada kurun ke sembilan. Umat Islam tertarik kepada metode argumentasi Yunani dari karya-karya falsafah dan saintifiknya yang diterjemahkan ke dalam bahasa Arab. Semangat pencarian Yunani mendominasi pandangan agama dan intelek golongan mutakallimin yang cuba merumuskan dan memberikan interpretasi yang kontroversial terhadap isu-isu kalam.

Tradisi kalam turut menjadi dasar dalam pemikiran rasional yang mengetengahkan metode argumentasi logis dan kaedah rasionalis. Ia menjadi benteng untuk mempertahankan agama berdepan dengan impak penemuan sains dan rempuhan falsafah Yunani dan mematahkan dakyah teologi yang dibawa oleh Kristiani. Pergelutan ide ini turut memberikan landasan dalam mengaplikasi akal kepada wahyu dan merekonsiliasi pemikiran Yunani dengan pilar-pilar Islam.

Dalam bukunya, Knowledge Triumphant, Franz Rosenthal (1970: 2) merumuskan bahawa peradaban Islam dibangun di atas tradisi akliah, yang 
telah mencetuskan penemuan saintifik dan kefahaman rasional dan membentuk asas pemikiran dan falsafah tradisional yang signifikan, "Islamic civilisation is one that is essentially characterised by knowledge ('ilm).. for 'ilm is one of those concepts that have dominated Islam and given Muslim civilization its distinctive shape and complexion". Tamadun Islam adalah satu yang secara esensinya bercirikan ilmu... kerana ilmu adalah salah satu konsep yang telah mendominasi Islam dan menyuguhkan peradaban Muslim bentuk dan coraknya yang tersendiri” Keupayaan akal dan kekuatannya yang ideal ini pernah diungkapkan oleh Imam Ali (kwj) dalam Wejangan Spiritual Imam Ali bin Abi Talib (kwj): "akal menjadikanmu sebagai pemilik zaman, sedangkan hawa nafsu memperbudakmu untuk zaman" (Sharif al-Rida, 2004).

Salah seorang ulama sekaligus ilmuwan pada abad pertengahan yang membicarakan tentang rasionalisme adalah Ibn Khaldun dalam karyanya alMuqaddimah, ia banyak mengupas tentang rasionalisme dalam buku tersebut. Untuk itu, Artikel lebih dikhususkan untuk mengupas kerangka pemikiran rasional yang diketengahkan Ibn Khaldun (1332-1406) dalam karyanya. Ia membahas aliran pemikiran rasional yang dilakarkannya dan pengaruhnya terhadap pemikir Islam modern, seperti Malik Bennabi, Rashid Ghannousyi dan Muhammad Asad. Penekanan yang luas diberikan kepada perbincangan manhaj pemikiran Ibn Khaldun dalam menggagaskan kefahaman Islam yang rasional, dan melihat kekuatan hujjah yang dilontarkannya dan dampaknya terhadap aliran mazhab dan fikrah Islam kontemporer. Ibn Khaldun mengungkapkan prinsip dan falsafah rasional yang signifikan dalam alMuqaddimah yang tuntas dipertahankan oleh Bennabi, Ghannoushi dan Muhammad Asad dalam karya-karya mereka, seperti Fenomena al-Qur'an: Esai tentang teori berkenaan al- Qur'an (Le Phenomene Coranique; essai d'une theorie sur le Coran), Asal Usul Masyarakat Manusia: Rangkaian Hubungan Sosial (On the Origins of Human Society: The Social Relations Network), Islam in History and Society, Question of Ideas in the Muslim World, al-Hurriyyah al'Ammah fi al-Dawlah al-Islamiyyah (Kebebasan Umum dalam Negara Islam) dan The Message of the Qur'an (Risalah alQur'an). Untuk menelaah pembahasan ini, penulis akan menggunakan metode penelitian perpustakaan dari jenis analisis kandungan secara deskriptif dan analitik.

\section{HASIL DAN PEMBAHASAN}

\section{Rasionalisme ibn Khaldun}


Ibn Khaldun, atau Waliy al-Din Abu Zayd 'Abd al-Rahman b. Muhammad b. Muhammad b. al-Hasan b. Jabir b. Muhammad b. Ibrahim b. 'Abd al-Rahman b. Khalid (Khaldun) al-Hadrami (732-808/1332-1406) adalah pemikir sejarah dan pengasas falsafah dan paham rasional Islam yang signifikan dengan karya-karyanya yang menekankan idealisme dan pemikiran rasional yang mendalam seperti diungkapkan dalam al-Muqaddimah dan al-Tbar. Kekuatan pengaruh Ibn Khaldun dan dampak pemikirannya yang luas terserlah dalam lapangan sosiologi, falsafah, sejarah, sains dan tamadun. Pengaruhnya yang luar biasa dalam tradisi pemikiran Islam telah mengangkat reputasi dan keunggulannya sebagai penemu historiografi, sosiologi dan ekonomi modern. Ide dan kerangka falsafahnya digambarkan oleh Albert Hourani (1983) sebagai "full reminders of the fragility of human effort" - out of his experiences [sarat dengan peringatan tentang kerapuhan daya usaha manusia - disingkap dari pengalamannya]. Arnold Toynbee (1987) dalam studinya tentang sejarah dan ikhtisarnya tentang penulisan dan falsafah Ibn Khaldun menulis 'he conceived and created a philosophy of history that was undoubtedly the greatest work ever created by a man of intelligence." [Beliau membayangkan dan melakar suatu falsafah sejarah yang tanpa ragu merupakan karya terhebat pernah dihasilkan oleh seorang pemikir]. Sejarah turut merekam sebagai pembela tradisi akliah, dan penegak hukum dan keadilan dan penggagas paham kebebasan dan prinsip kebudayaan yang inklusif dan dinamis, seperti dicatatkan oleh al-Sakhawi tentang perannya sebagai Qadi "was well-known by the maintenance of justice" (Fuad Baali 1988: 4).

Ibn Khaldun mempelopori asas pemikiran rasional yang bersandar kepada landas dan manhaj akliah, upaya taakul, dan analisis yang pragmatik yang berpijak dari kaidah eksperimental dan saintifik. Beliau mengembangkan kaedah skeptikal yang digariskan oleh al-Ghazali dalam kitabnya al-Munqidh min al-Dalal dan Miraj al-Quds. Dalam kitab al-Muqaddimah, beliau membahaskan falsafah yang bersandar kepada intelek dan silogisme logika dan mengkritik pandangan filsuf dan mematahkan hujjah mereka, khususnya dalam metafizik. Menurutnya penghujahan filsuf hanya menampakkan penzahiran falsafah yang cemerlang, tanpa mencipta sesuatu dalil atau pembuktian. Silogisme dan sintesis mereka dikonstruksi hanya berdasar kondisi yang mereka keluarkan dari karya logis mereka. Namun, dengan cara pembuktian yang tidak mencukupi ini, ia telah menyuguhkan kerangka teori yang terbaik yang dapat diketengahkan. Persepsi rasionalnya banyak terpengaruh dengan pandangan al- 
Ghazali dan Plato yang mengetengahkan falsafah rasional dan asumsi-asumsi dasar yang beralasan dan realistik. Ibn Khaldun telah menggariskan faham sejarah, sosiologi, agama dan budaya yang signifikan yang menggariskan pandangan dan pesan-pesan rasional yang esensial. Tinjauan ini cuba menyorot aspek pemikiran rasionalisme Ibn Khaldun, dan perbincangannya yang mendalam terkait hujah-hujah falsafah dan kalam dan pengaruhnya dalam perkembangan sejarah modern.

\section{Pengaruh Rasionalisme ibn Khaldun}

Dalam memahami prinsip rasionalisme Ibn Khaldun, dan pandangannya terkait prinsip dan paham rasional Islam, tulisannya banyak mempengaruhi interpretasi falsafah dan kaedah intelektual yang diangkat oleh para pemikir Islam modern seperti Malik Bennabi, Rashid Ghannouchi dan Muhammad Asad. Dari landasan dan pengaruh intelektualnya, mereka mengambil dasar pikiran yang terkesan membawa idea dan paham rasional yang dipeloporinya. Hal ini cuba ditinjau dalam penelitian yang selanjutnya tentang pengaruh yang dibawa dari fikrah dan tradisi falsafah Ibn Khaldun ini dalam pemikiran mereka.

Malik Bennabi (1903-1973/1323-1393) pemikir Islam asal Algeria yang terkenal dengan idenya tentang asal-usul bangsa, aspirasi kebangkitan (yang dianalisis dalam bukunya Prasyarat Kebangkitan (Les conditions de la renaissance) [1948]) dan teori peradaban banyak terkesan dengan pandangan dan gagasan rasionalisme Ibn Khaldun. Beliau mengagumi kekuatan falsafah dan konsepsi sejarah Ibn Khaldun dan menyatakannya sebagai sosok penting dalam sejarah pemikiran dan tradisi rasional Islam. Beliau menyifatkan karya-karya klasik Ibn Khaldun sebagai penzahiran rasionalisme Islam yang tulen. Ini terlukis dalam penulisan dan pemikirannya yang prolifik. Bennabi mengkaji punca kejatuhan tamadun seperti dinasti Almohad di Afrika Utara dan empayar Islam di Spanyol, yang telah menyingkirkan peranan Islam sebagai kuasa besar dunia. Kekalahan kepada penjajah telah membelenggu dan mengikat pergerakan umat, yang ditewaskan oleh sikap permisif dan mengalah kepada imperialis dan kolonialis, dan diburukkan dengan masalah kepincangan moral, kegawatan idea dan peradaban yang bankrup.

Analisis Bennabi mengarah kepada pencerahan dan revitalisasi ide, pemugaran fikrah dan kelahiran falsafah rasional, kebangkitan budaya dan pemacuan tradisi akliah yang segar. Dalam bukunya, Les Conditions de la 
renaissance, beliau mengupas tuntutan memperbaharui tamadun dan budaya estetik, etika, melonjakkan semangat renaisans dan kompetensi teknikal yang pragmatik yang menambahkan masyarakat yang dinamik, dan formulasi ide yang dapat berkembang. Dalam bukunya the Question of Culture (1954), beliau menganalisis persoalan budaya yang pincang dan bobrok dalam masyarakat. Menurutnya organisasi kehidupan dan pergerakannya malah pengherotan dan stagnasinya, mempunyai hubungan yang rapat dengan sistem ide dalam masyarakat tersebut.

Teori dan falsafah rasional yang dibincangkannya menekankan kepentingan menjelmakan ijtihad dan menolak amalan taklid yang bobrok dan jahil, yang memperbodohkan akal, kerana "kejahilan hakikatnya adalah kemusyrikan kerana ia tidak memupuk fikiran, tetapi memahat berhala."

Rashid Ghannouchi (1941) turut diilhamkan oleh tradisi rasional Ibn Khaldun. Ia merupakan seorang aktivis dan politikus Muslim asal Tunis yang memimpin harkat perjuangan yang penting di Tunisia. Ia membawa semangat kebebasan dan kebangkitan (nabda) yang radikal. Ghannouchi adalah pemimpin Hizb an-Nabdah, Partai Renaisans. An-Nahdah diasaskan pada 1988 setelah Ghannouchi dibebaskan dari penjara kerana aktivisme politiknya dengan Harakah al-Ittijah al-Islami (Islamic Tendency Movement) yang diasaskan pada awal 1981. Ketika mendekam di penjaralah Ghannouchi meraih kesempatan yang luas untuk bertafakur dan menyingkap ide-ide Muhammad Abduh - yang telah melawat Tunis sebanyak dua kali dan mengikat jaringan perhubungan di sana - dan dengan banyak ulama Islam yang lain termasuk Ibnu Asyur dan Malik Bennabi.

Ghannouchi merupakan seorang pemikir yang unik dan terkehadapan di kalangan yang lain dalam mencanangkan demokrasi Islam, dan pernah hidup dalam buangan di England. Beliau disingkirkan pada 1989 dan setelah 22 tahun, pulang ke tanah airnya Tunisia pada Januari 2011 dan dijulang sebagai wira. Partai Ghannoushi Hið̧b an-Nabdah - Partai Renaisans - memenangi pilihanraya pertama yang bebas di Tunisia, sepuluh bulan setelah tercetusnya kebangkitan yang menjatuhkan pemimpin, Zine al-Abidine Ben Ali, yang telah mengharamkan pertubuhan tersebut dan memenjarakan Ghannoushi sebelum beliau memutuskan untuk hidup dalam buangan di London. Hiø̧b an-Nabdah berikrar untuk meneruskan demokrasi setelah undian pertama yang terhasil dari revolusi "Dunia Arab" menzahirkan dampaknya ke Timur Tengah dan Afrika Utara. 
Dalam buah karyanya ia mempelopori semangat pencerahan dan rasionalisme Islam yang tulen yang diilhamkan dari tulisan Ibn Khaldun, seumpama al-Muqaddimah. Ghannouchi terkesan dengan pandangan dan kefahaman Islam rasional yang dibawa Ibn Khaldun dan Malik Bennabi dalam analisisnya tentang sejarah, falsafah, sosiologi dan peradaban Muslim. Asas pemikiran rasional dan cita-cita pembaharuannya dan pengaruh kritikal Ibn Khaldun dan Malik Bennabi terhadap Ghannouchi ini jelas dalam perumusannya tentang demokrasi Islam. "Malik Bennabi, pemikir Algeria; yang diraikan Ghannouchi sebagai pasak pemikiran Islam dan pemicu gagasan rasionalisme Ibn Khaldun, mempunyai pengaruh yang besar terhadapnya. Ghannouchi melihat rasionalisme Islam sebagai penduan akal dan wahyu yang menelantarkan sumber pengetahuan. Hubungan wahyu dengan akal adalah seperti penglihatan dengan cahaya; salah satu tidak dapat wujud tanpa yang lainnya." (Farouk Musa, 2012: 14)

Ketika di penjara, Ghannouchi menerjemahkan syarahan Bennabi dalam bahasa Perancis ke bahasa Arab dengan judul Ad-Dimuqratiyah filIslam (Demokrasi dalam Islam). Dalam tretis inilah Ghannouchi menemui jawapan kepada satu persoalan yang musykil "Adakah wujud demokrasi dalam Islam? Bennabi, menurut Ghannouchi, menekankan bahawa jawapan terhadap persoalan tersebut tidak semestinya diambil dari hukum fiqh (jurispruden) yang dirumuskan daripada al-Qur'an atau Sunnab; tetapi dapat digarap daripada kefahaman yang komprehensif terhadap intipati Islam. Model demokrasi Islam tidak hanya setakat mengurniakan manusia dengan mandat dan hak politik atau sosial, tetapi akan memberkahinya dengan nilai yang mengatasi setiap nilai politik atau sosial, nilai yang diisytiharkan dalam al-Qur'ān ayat 70, surah 17: "Kini, sesunggubnya, Kami telah meninggikan darjat anak-anak Adam." Ayat ini diturunkan seakan menggariskan asas bagi sebuah model demokratik yang mengalahkan setiap model yang lain, di mana elemen suci di dalam diri manusia diangkat sebagai pertimbangan dan tidak hanya aspek manusiawi atau sosial seperti dalam model yang lain. Dengan itu, satu bentuk kesucian dikurniakan kepada manusia; yang mengangkat martabatnya atas apa jua nilai yang dikalungkan oleh model yang lain.

Beliau menganggap penderitaan yang ditanggung dari pemenjaraannya yang pertama sebagai suatu pemberian dari takdir kerana ia membawa beliau jauh daripada kegusaran masalah-masalah harian, dan mencampakkan beliau ke dalam sebuah keadaan dimana beliau dapat bekerja bertungkus lumus untuk 
merespon kepada cabaran-cabaran yang dihadapi (Ghannouchi, 2011: 17). Pendekatan Bennabi dalam menangani persoalan tentang hubungan antara Islam dan demokrasi menunjukkan bahwa perdebatan yang rancak mengenai isu tersebut telah berjalan sejak awal tahun 1960-an di kalangan pelajar-pelajar Afrika Utara di Paris. Ada kemungkinan bahwa Ghannouchi telah diilhamkan daripada perdebatan yang diperbaharui di negaranya sendiri pada lewat tahun 1970-an untuk mengkaji syarahan Bennabi dan menterjemahnya ke dalam bahasa Arab bagi membolehkannya dibaca oleh kaum Islamis yang kearaban di dalam gerakannya. Berkemungkinan juga bahawa beliau mahu idea-idea Bennabi dibaca oleh para Islamis di Mashriq yang kritis terhadap komitmen terbuka gerakan Islam Tunisia terhadap demokrasi.

Beliau menghabiskan selama dua tahun penuh dalam kerja keras untuk menyerap semua yang dapat dicapainya dari rujukan-rujukan yang relevan. Sungguhpun dengan pemenjaraannya, beliau masih dibenarkan - berkat simpati dan sikap tolerer yang ditunjukkan oleh sebahagian pengawal penjara untuk membawa masuk buku-buku dan bahan rujukan yang dimintanya. Beliau menjalankan beberapa proyek, salah satunya adalah mengkaji terjemahan sebuah buku tentang wanita yang dikarang oleh Roger Garaudy, yang telah mengilhamkannya - berserta dengan pengalaman beliau di Sudan tidak lama sebelum itu - untuk menulis sebuah risalah tentang hak-hak wanita dan status wanita di dalam gerakan Islam. Buku Garaudy dalam versi bahasa Arab membawa judul Fi-Sabil Irtiga 'al-Mar'ah (Ke arah memartabatkan kaum Wanita) (Buku ini diterjemahkan oleh Jalal al-Matrahi dan diterbitkan di Tunisia. Karya asalnya, yang diduga dalam bahasa Perancis, tidak dapat dikesan dan tiada butiran mengenainya diberikan dalam edisi bahasa Arab). Bagaimanapun projek yang lebih penting adalah terjemahannya ke atas risalah kecil yang ditulis oleh Malik Bennabi berjudul Al- Islam Wad-Dimuqratiyah (Islam dan demokrasi), dan memulakan projek untuk menyusun karyanya yang terpenting, Al-Hurriyat al-'Ammah Fid-Dawlah al-Islamiyyah (Kebebasan umum dalam negara Islam). Sebahagian dari penulisan Ghannouchi semasa menjalani hukuman penjara, termasuklah terjemahannya keatas tretis Bennabi, yang diterbitkan dengan menggunakan nama pena Mu'adh as-Sabir (yang terbit pada tahun 1983 oleh Dar ar-Rayah di Tunisia dengan judul Al-Islam WadDimuqratiyah. Ghannouchi dibantu dalam penerjemahan buku ini oleh an-Nuri, koleganya dalam penjara). Penerbitan yang memakai nama pena ini termasuk sebuah risalah tentang Palestina bertajuk Al-Qadiyah al-Falastinyah 'Ala Muftaraq 
Tariq (Isu-isu Palestin di Persimpangan) dan sebuah artikel yang mengkritik rezim Iran di bawah Khomeyni (Ghannouchi, 1984).

Ghannouchi mengungkapkan hasrat kebebasan dengan rencana politik yang rasional, yang diasas kepada falsafah dan kefahaman rasionalisme Islam seperti dikupas oleh Azzam S. Tamimi (2001: 215): "the significance of Ghannouchi also emanates from the facts that, unlike other Islamic thinkers who espouse the democratic cause, he is both a thinker and a leader of an Islamic movement. He is a credible authority within Islamic circles at the global level. His thoughts are in no way restricted to an intellectual debate at a time when the Islamic movement has emerged as a major political power in the Muslim world, and when power-sharing or power taking experiments are in process. Ghannouchi is unprecedented within Islamic intellectual circles in his theory that civil society is an Islamic concept and that religion consolidates civil society whereas secularism, especially the model imported to the Muslim world under the guise of modernization, weakens it".

Kepentingan Ghannouchi juga lahir daripada kenyataan bahawa, tidak seperti pemikir Islam yang lain yang mendukung perjuangan demokrasi, beliau juga adalah pemikir dan pemimpin gerakan Islam. Beliau adalah autoriti yang berwibawa dalam lingkaran Islam pada peringkat global. Pemikirannya sama sekali tidak terbatas kepada perdebatan intelektual pada masa ketika gerakan Islam telah bangkit sebagai kuasa politik yang utama di dunia Islam, dan ketika perkongsian-kuasa atau pengalaman pengambilan kuasa sedang dalam proses. Ghannouchi tiada taranya dalam lingkaran intelektual Islam dalam teorinya bahawa masyarakat sivil merupakan konsep Islam dan bahawa agama memperkukuhkan masyarakat sivil sementara sekularisme, terutamanya model yang diimpor ke dunia Islam di bawah kedok modernisasi, melemahkannya.

Ia adalah pemikir Islam yang pertama yang menangani permasalahan yang menantang peralihan kepada demokrasi di dunia Arab dengan cara yang telah dianalisis oleh Azzam S. Tamimi dalam bukunya ini Rachid Ghannouchi: $A$ Democrat Within Islamism. Beliau mula membangunkan tesis ini berikutan rampasan kuasa terhadap demokrasi di Algeria pada tahun 1992, kurang daripada dua tahun setelah kegagalan pengalaman demokratik di negaranya sendiri, Tunisia. Kepentingan Rachid Ghannouchi terserlah daripada standard yang tinggi dari wacana politiknya, yang unik dengan percubaan berani untuk memperbaharui dan memperkenalkan dimensi baru dalam pemikiran Islam kontemporer. Impak dari penampilan ideologi dan intelektualnya telah jauh 
melangkahi perbatasan Tunisia. Sumbangannya kepada pemikiran Islam modern terletak dalam pemahamannya terhadap kedua-duanya literatur Islam tradisional dan konsep-konsep moden Barat dan dalam kepercayaannya yang kuat pada teori kesejajaran antara Islam dan pemikiran Barat dalam hal berkait sistem kerajaan, hak asasi dan kebebasan sipil.

Setelah berhasil menerjemahkan karya Bennabi Ad-Dimuqratiyah filIslam (Demokrasi dalam Islam), Ghannouchi memutuskan untuk menulis sebuah buku tentang kebebasan. Diterbitkan pada 1993, Al-Hurriyah al-'Ammah fidDawlah al-Islamiyyah (Kebebasan Umum dalam Negara Islam), dianggap sebagai salah satu karya terpenting dalam wacana pemikiran politik Islam semasa. Dalam buku ini, Ghannouchi melihat demokrasi sebagai kesan dari evolusi sejarah yang panjang. Beliau berhujah bahawa kaum Eropah mengambil faedah dari peradaban Islam dengan kerangka konsepsi pencerahan yang segar mengenai nilai sosial yang hasilnya adalah kebangkitan demokrasi liberal. Dengan kata lain, demokrasi adalah versi Barat daripada syūra Islam (konsensus). Pemimpin Islam setelah era Khalifah Rasyidun telah menggantung amalan syüra dalam upaya pemilihan pemimpin. Penggantungan ini terus berlangsung sehingga ke abad moden ketika bangsa lain mengatasi umat Islam dalam mengiktiraf kebebasan bersuara dan mempertahankan kebebasan politik. Secara metaforik, ketika pohon syüra layu di tanah Islam kerana kurang dibaja, benihnya mekar, yakni ketika musim Renaisans, di tanah Eropah di mana pohon demokrasi berakar dan berkembang.

Tema utama dalam pemikiran Ghannouchi adalah demokrasi sejajar dengan Islam, dan umat Islam harus menggabungkannya dalam pemikiran politik mereka bagi menginstitusikan konsep syüra (perundingan). Ghannouchi menekankan bahawa yang lebih penting, nilai-nilai asas demokrasi yang ditimbulkan di zaman Nabi (saw) dan al-Khiläfah ar-Räsyidah (Khalifah yang mendapat Petunjuk) dilaksanakan berlandaskan pada prinsip, dan bukan pada model. Beliau berhujah bahawa permusuhan sebahagian dari puak Islamis terhadap demokrasi adalah disebabkan pemahaman yang dangkal tentang karakter Islam dan juga mengenai sejarah perkembangan pendekatan umat Islam menangani persoalan tentang kerajaan. Beliau mengetengahkan idea bahwa Islam meliputi faraghat (ruang) atau lapangan yang dibiarkan kepada manusia memenuhinya mengikut keperluan dan tuntutan waktu dan tempat.

Untuk memperkukuhkan ideanya, Ghannouchi menyingkap sejarah ketika peperangan Badr, pertempuran pertama dalam sejarah Islam. Nabi (saw) 
mengarahkan tentaranya untuk merebut posisi yang dapat meninggalkan kedudukan perigi antara mereka dan pasukan musuh. Seorang Sahabat bernama al-Habbab ibnul-Munzir (rad) bertanya sama ada percaturan ini adalah ketentuan wahyu dari Tuhan atau masih dalam lingkungan ar-rä'iy walharb wal-makidah (pendapat dan strategi perang). Nabi (saw) menjawab ia hanya bersandarkan ijtihad. Sahabat tersebut, yang merupakan komander perang yang berpengalaman, mencadangkan bahawa kebijakan mengambil lokasi ini bukan langkah yang terbaik dan strategik, dan adalah lebih baik untuk menempatkan pasukan militer di hadapan perigi supaya pihak musuh tidak dapat tembus laluan ke punca air. Nabi (saw) bersetuju dan rencana Sahabat tersebut dilaksanakan.

Kenyataan yang Ghannouchi ingin ketengahkan adalah struktur binaan Islam, yang ditinggalkan oleh Nabi (saw), telah sempurna pada garis asas dan struktur komponen yang berkait dengan ad-deeni (agama). Selain dari itu, para sahabat (rad) tidak teragak-agak untuk menanggapi bidang kedua dari faragh (ruang), di mana mereka juga dapat mengemukakan ijtihäd jika dan bilamana perlu, sama ada ketika bersama Nabi (saw) atau setelah kewafatan Baginda (saw). Yang bermakna, struktur komponen yang menyentuh tentang as-siyäsi ditinggalkan untuk generasi kemudian merangka dan memperbaikinya.

Kepentingan utama Ghannouchi adalah untuk menekankan keperluan mewujudkan demokrasi, untuk membuktikan kesejajarannya dengan Islam dan untuk menganalisis halangan yang menghambat kejayaannya di dunia Islam. Bagaimanapun, demokrasi mempunyai musuhnya, baik dari arah lokal dan internasional; dan banyak halangan yang akan menyekat kemajuannya. Ghannouchi ingin menekankan bahwa perjuangan menentang halangan eksternal terhadap demokrasi di dunia Islam, adalah sama penting dengan perjuangan membanteras halangan dalaman melalui pendidikan, pembacaan semula sejarah Islam, dan pemugaran ijtihäd.

Muhammad Asad (1900-1992) turut terkesan dengan mazhab rasional yang dilontarkan Ibn Khaldun dalam magnum opusnya al-Muqaddimah. Asad merupakan seorang penafsir, diplomat, wartawan, penulis dan penerjemah yang aktif mengusung pesan perubahan, dan menghidupkan warisan intelek dan tradisi akliah yang segar. Beliau mempelopori kebangkitan ijtihad dan membela ide-ide rasional Ibn Khaldun dalam al-Muqaddimah. Faham rasional ini diungkapkan dengan jelas dalam adikaryanya The Message of The Qur'an: "Every Qur'anic verse or statement is directed to reason and therefore must 
be comprehensible [setiap ayat atau pernyataan al-Qur'an ditujukan kepada akal dan kerana itu harus dapat difahami], dan “'The spirit of the Qur'ān could not be correctly understood if we read it merely in the light of later ideological developments, losing sight of its original purport and meaning. In actual fact we are bent to become intellectual prisoners of others who were themselves prisoners of the past and had little to contribute to the resurgence of Islam in the modern world." (Muhammad Asad, 1980: 19) Semangat al-Qur'an tidak dapat dipahami sepenuhnya sekiranya kita membacanya hanya dalam rangka perkembangan ideologi setelahnya, terlepas dari menilik tujuan dan maknanya yang asli. Pada kenyataan yang sebenar kita telah terikat dan menjadi tawanan intelek kepada yang lain yang juga telah tertawan oleh pemikiran yang lepas dan hanya sedikit yang dapat disumbangkan kepada kebangkitan Islam dalam dunia modern.

The Message of The Qur'an mengemukakan konsep dan falsafah pemikiran yang rasional yang cuba menjawab tuntutan zaman secara realistik dengan pandangannya yang tuntas dan autentik. "Setiap zaman menuntut pendekatan yang baru terhadap al-Qur'an dengan alasan yang mudah bahwa al-Qur'an diturunkan untuk semua zaman. Ia merupakan tugas kita untuk mencari makna yang lebih mendalam di dalam al-Qur'an bagi meningkatkan pengetahuan dan pengalaman kita. Al-Qur'an ingin daya intelek anda sentiasa aktif dan cuba untuk mendekati pesan ketuhanan. Tuhan sendiri mendedikasikan kitab ini kepada mereka yang berfikir." (Muhammad Asad, 1980: 13) Penafsirannya yang jitu dan keaslian ide yang dilontarkan menzahirkan pemikirannya yang kritis dan ideal tentang sejarah, falsafah dan fikrah Islam. Tafsirannya disandarkan dari penghujahan teks-teks klasik dan kontemporer dan karya-karya tafsir yang mu'tabar yang dirujuknya secara ekstensif seperti tafsir Al-Tabari, Al-Zamakhshari, Ibn Hazm, Al-Razi, AlBaydawi, Abi Su'ud, Al-Qurtubi, Ibn Kathir, Al-Suyuti, Muhammad Abduh dan Rashid Rida.

Tafsirannya terhadap teks al-Qur'an memperlihatkan kefahamannya yang tuntas terhadap khittah dan pesan hukum dan ideal syariah yang diungkapkan dalam al-Qur'an. Tafsirnya memberi penekanan yang penting untuk mengangkat nilai Islam yang universal dan menjelaskan fikrah dasarnya yang inklusif dan rasional dan menguraikan pemikiran dan fahaman maqasid yang meluas yang diutarakan di dalam al-Qur'an. Gagasan pembaharuan yang radikal jelas diperlihatkan dalam tafsiran dan kupasan ayat-ayat al-Qur'an yang 
ditafsirkannya secara alegoris dan konteks asal kewahyuan dengan meraikan realiti (waqi') dan perkembangannya dalam sejarah.

Kupasannya memperlihatkan upaya tafsir yang kritis dan rasional. Ia merangkul perbincangan hukum dan mazhab yang meluas yang mempertahankan kekuatan hujjah dan fikrah yang rasional dan meraikan prinsip maqasid dan maslahah: "Islam harus dikemukakan tanpa sebarang fanatisme. Tanpa sebarang penekanan hanya kita yang menempuh jalan petunjuk dan kalangan yang lain tersasar. Kesederhanaan dalam semua bentuk adalah tuntutan basis dalam Islam" (Muhammad Asad, 1980).

Asad menggagaskan prinsip Islam yang moderat dengan tafsiran yang ekstensif bersandarkan hujah akliah yang meyakinkan. Tafsirnya merupakan sebuah komentar al-Quran yang terbaik dengan penjelasan yang jitu yang dirangkul dan dirumuskan dari pandangan mufassir dan fuqaha yang muktabar. Ia telah melahirkan sumbangan yang bermakna dalam mengangkat kefahaman Islam yang kritis dan memugar tradisi akliah yang mengesankan. Kekuatan tafsirnya The Message of the Qur'an adalah pemahaman dasarnya terhadap aspirasi Islam yang rasional dan prinsip akliah dan kebebasan. Ia merumuskan faham dan intipati maqasid yang mendasar yang digarap dari pandangan dan semangat al-Qur'an. The Message of the Qur'an merumuskan makna yang signifikan dari perbahasan linguistik, idiomatik, dan hermeneutik al-Qur'an yang memperdalam pemahaman terhadap kesan-kesan alegoris ayat-ayatnya bagi kaum yang berfikir (li qawm yatafakekarun).

Kriteria penting yang diperlihatkan dalam The Message of the Qur'an adalah penekanannya terhadap upaya ijtihad dan istinbath dan takwil, pendalamannya tentang nilai-nilai sejarah, falsafah, dan etika, penolakannya terhadap riwayat Israiliyat, komentarnya yang bermakna terhadap ushul tafsir, hadits, teologi dan fikah, dan rujukan yang ekstensif terhadap kitab-kitab tafsir klasik dan modern, serta perumusannya terhadap teori-teori hukum dan falsafah, dan penggarapan tema-tema pokok dari setiap surah. Keutamaan dalam perbahasan adalah gagasan moral, rasionalitas dan pembaharuan, dan perbincangan seputar falsafah sejarah dan latar yang signifikan dari setiap surah (asbab al-nuzul).

Pencerahan yang dibawa dari karya tafsir Muhammad Asad ini telah mencetuskan paham pembaharuan yang meluas di dunia Islam yang terkesan dari idealisme moden yang digagaskan Tafsir al-Manar oleh Shaykh Muhammad Abduh dan Muhammad Rashid Rida yang terkesan oleh fahaman rasional dan 
saintifik dan gerakan pan Islamisme Sayyid Jamal al-Din al-Afghani. Gerakan ini telah mempengaruhi dan mengilhamkan kebangkitan ide rasional dan perjuangan nahdah yang bermakna di dunia Islam. Aspirasi Islam yang diungkapkan oleh Muhammad Asad wajar diperjuangkan dan digerakkan dengan meluas bagi mengangkat dan melanjutkan idealisme pembaharuan yang dicetuskannya bagi mengangkat kekuatan daya akliah dan ijtihad.

Dalam tulisannya yang lain "Islam at the Crossroads" (Islam di Simpang Jalan), Muhammad Asad menekankan kerasionalan dan peranan sosial hadith dalam kehidupan umat. Ditilik dari tulisannya ini, nescaya kita menyedari penekanan yang kuat yang diletakkannya terhadap umat Muslim untuk berpegang pada ajaran al-Qur'an dan Sunnah. "Sunnah," beliau tekankan, "adalah kunci untuk memahami kebangkitan Islam lebih dari tiga belas abad yang lalu; dan mengapa ia tidak harus menjadi kunci untuk memahami keterbelakangan kita hari ini?" Tetapi kemudian beliau menulis: "Ini tidak bermakna bahwa umat Islam harus menjauhkan diri mereka daripada suara yang datang daripada luar. Seseorang bisa pada segenap masa menerima pengaruh baru, positif dari tamadun asing tanpa semestinya menyingkirkan tamadunnya sendiri." (Muhammad Asad, 1990: 30)

Asad menyambung: "Contoh dari jenis ini adalah Renaisans Eropah. Kita telah melihat bagaimana siapnya Eropah menerima pengaruh Arab dalam isi dan manhaj pembelajaran. Tetapi ia tidak pernah bertaklid kepada kerangka zahir dan semangat kebudayaan Arab, dan tidak pernah mengorbankan mandiri intelektualnya dan kemerdekaan estetiknya. Ia menggunakan pengaruh Arab hanya sebagai penyubur kepada tanahnya sendiri, sebagaimana bangsa Arab telah menggunakan pengaruh Helenistik pada zaman mereka. "Dalam kedua-dua kes, natijahnya adalah pemerkayaan rohani, pertumbuhan baru, yang kuat dari sebuah peradaban yang asli, sarat dengan keyakinan-diri dan kebanggaan dalam dirinya. Tiada peradaban dapat berkembang, atau malah wujud, setelah hilang kebanggaan ini dan hubungan dengan zaman silamnya sendiri." (Muhammad Asad, 1990: 31)

\section{KESIMPULAN}

Rasionalisme yang dicetuskan Ibn Khaldun terhadap pemikir Islam sangat penting. Pemikiran rasional yang diperjuangkan bagi mengangkat kekuatan akliah dan ijtihad telah membawa perubahan yang bermakna dalam menghidupkan semula asas rasional dan tradisi intelektual Islam di zaman 
pertengahan. Kerangka besar dari paham rasional dan kritikal yang digagaskan Ibn Khaldun, dan dimunculkan semula oleh Malek Bennabi, Rashid Ghannouchi dan Muhammad Asad telah menyumbang kepada perubahan yang signifikan dalam harakat pemikiran moden yang menzahirkan idealisme dan cita-cita perubahan yang kental bagi mengangkat dan mengemukakan kerangka pemikiran yang dinamis dan mencetuskan pandangan Islam yang rasional dan kritis. Paham rasionalisme ini terus didengungkan sebagai landasan dan dasar pemikiran yang ideal yang menjadi keutamaan dalam fikrah Islam kontemporer yang meraikan prinsip maqasid, nilai-nilai saintifik, kaidahkaidah maslahah dan kefahaman agama yang terbuka, dan rasional.

\section{DAFTAR REFERENSI}

Abrahamov, Benyamin (1998). Islamic Theology: Traditionalism and Rationalism. Edinburgh: Edinburgh University Press.

Ahmad Farouk Musa ed. (2012). Wacana Pemikiran Reformis. Kuala Lumpur: Islamic Renaissance Front.

Asad, Muhammad (1980). The Message of the Qur'an. Gibraltar: Dar al-Andalus. Asad, Muhammad (1990). Islam at the Crossroads. Islamabad: Dakwah Academy, International Islamic University.

Bennabi, Malik (1998). On the Origins of Human Society: The Social Relations Network. Mohamed T. El-Mesawi (tr.). Petaling Jaya: Islamic Book Trust.

Bennabi, Malik (2001). Quranic Phenomenon - an Essay of a Theory on the Quran. Mohamed T. El-Mesawi (tr.). Petaling Jaya: Islamic Book Trust.

Bennabi, Malik (2007). Asal Usul Masyarakat Manusia: Rangkaian Hubungan Sosial. Muhammad Uthman El-Muhammady (tr.). Kuala Lumpur: Institut Terjemahan Negara Malaysia.

Bennabi, Malik (2009). Fenomena Al-Quran: Esei tentang Teori Berkenaan al-Qur'an. Rosiyah Abd. Latif (tr.). Kuala Lumpur: Institut Terjemahan Negara Malaysia.

Franz Rosenthal (1970). Knowledge Triumphant: The Concept of Knowledge in Medieval Islam. Leiden: Brill. 
Fuad Baali (1988). Society, State, and Urbanism: Ibn Khaldun's Sociological Thought. Albany: State University of New York.

Ghannouchi, Rachid (1984). Adh-Dhikera ath-Thalitha Liharakat al-Ittijah al-Islami (Kenang-kenangan ulangtahun ketiga MTI) [Islamic Tendency Movement], Carthage, 6 Jun.

Ghannouchi, Rachid (2011). Al-Hurriyat al-Ammah fi al-Daulat al-Islamiyyah. Bayrut: Dar al-Mujtahid lil Nashr wal Tawzi'.

Hourani, Albert Habib (1983). Arabic Thought in the Liberal Age, 1798-1939. Cambridge: Cambridge University Press.

Hourani, George F. (1971). Islamic Rationalism: The Ethics of 'Abd al-Jabbar. Oxford: Clarendon Press.

Ibn Khaldun, 'Abd al-Rahman (2001). Tarikh Ibn Khaldun. Khalil Shahadah (ed). Dar al-Fikr.

Ibn Khaldun, 'Abd al-Rahman (2005). The Muqaddimab: an Introduction to History. Franz Rosenthal (tr.). Princeton, N.J.: Princeton University Press.

Ishak, Mohd Shuhaimi (2007). "Islamic Rationalism: A Critical Evaluation of Harun Nasution's Thought." Tesis Phd, Kulliyyah of Islamic Revealed Knowledge and Human Sciences, IIUM.

Nasution, Harun (1995). Islam Rasional: Gagasan dan Pemikiran. Bandung: Mizan.

Sharif al-Rida, Muhammad b. al-Husayn (2004). Nahj al-Balaghah. Beirut: Mu'assasat al-Ma'arif lil-Tiba'ah wa'l-Nashr.

Tamimi, Azzam (2001). Rachid Ghannouchi: A Democrat within Islamism. Oxford: Oxford University Press.

Toynbee, Arnold Joseph (1987). A Study of History. New York: Oxford University Press. 